\title{
ИСТОЧНИКИ ЦЕННЫХ ПРИЗНАКОВ КАРТОФЕЛЯ (Solanum L.) ПО ПЛАСТИЧНОСТИ И СТАБИЛЬНОСТИ В УСЛОВИЯХ СЕВЕРНОЙ ЛЕСОСТЕПИ ЗАПАДНОЙ СИБИРИ*
}

\author{
В.Н. ПАКУЛЬ, Н.А. ЛАПШИНОВ, А.Н. ГАНТИМУРОВА, В.И. КУЛИКОВА
}

Среди сортов картофеля для производителя наиболее ценны высокопродуктивные, обладающие комплексом признаков (в том числе устойчивостью к болезням и вредителям) с относительной стабильностью урожая в варьирующих условиях выращивания. При создании высокопродуктивных адаптивных сортов картофеля для регионов с жесткими агроклиматическими условиями важен подбор исходного материала с высокой экологической пластичностью и стабильностью в конкретной зоне возделывания. В представленных исследованиях впервые дана оценка нового исходного материала картофеля, созданного в почвенно-климатических условиях Западной Сибири, имеющего высокую урожайность, комплексную относительную устойчивость к грибным болезням, Ү-вирусу картофеля и золотистой картофельной нематоде. Выделенные новые генетические источники картофеля используются в практической селекции на продуктивность и высокую адаптивность. Цель работы - определить показатели адаптивности у исходного материала картофеля в условиях северной лесостепи Западной Сибири (Кузнецкая котловина, Кемеровская обл., Кемеровский р-н). Эксперименты проводили в 2014-2018 годах. Общая площадь делянки - $70 \mathrm{~m}^{2}$, учетная - $20 \mathrm{~m}^{2}$, повторность 4-кратная, варианты размещались рендомизированно. Посадку проводили в III декаде мая картофелесажалкой Cramer («CRAMER Technik», Германия) с нормой 35,0 тыс/кустов на 1 га, схема посадки $70 \times 35$ см. Исследовали 170 образцов в коллекционном питомнике, в том числе коллекционные гибриды картофеля (Solanum tuberosum L.), созданные в Кемеровском НИИ сельского хозяйства (филиал СФНЦА РАН). Стандартом служили сорта Любава (ранний), Невский (среднеранний) и Тулеевский (среднеспелый). В результате исследования среди коллекционных образцов картофеля выделены генотипы экстенсивного тип с низкой экологической пластичностью $\left(b_{i}\right.$ менее единицы $\left.-0,28-0,91\right)$ : сорта Любава, Невский, Тулеевский и гибриды 6-4-11, 22103-10. Наибольшей реакцией на условия выращивания выделился гибрид 3-21c-11 (b $\left.b_{i}=1,53\right)$, имеющий среднюю стабильность по урожайности $\left(\mathrm{S}_{\mathrm{i}}{ }^{2}=14,6\right)$. Гибриды 22103-10 и 3-21с-11 являются донорами генов устойчивости к Y-вирусу картофеля $\left(R y_{c h c}\right)$, золотистой картофельной нематоде Globodera rostochiensis (Woll.) (H1) и бледной нематоде Globodera pallida (Stone) Behrens (Gpa2). По комплексной оценке особую ценность для селекции представляют три гибрида интенсивного типа (17-5/6-11, 1-5-12 и 1615-10), проявляющие высокие адаптивные свойства - повышенную экологическую пластичность $\left(b_{i}\right.$ соответственно 1,$38 ; 1,20$ и 1,17$)$ и высокую стабильность $\left(S_{i}^{2}\right.$ соответственно 1,$1 ; 9,4$, 5,2). При этом гибрид 17-5/6-11 проявил себя как донор генов устойчивости к Y-вирусу картофеля (Potato virus Y, PVY) (Rychc) и к золотистой картофельной нематоде (H1 по трем маркерам TG 689, 57 R, N 195). Генотип гибрида 1-5-12 содержит комбинацию генов H1 (все три маркера) и Gro1-4 (контролируют устойчивость к G. rostochiensis), а также ген Gpa2 (устойчивость к G. pallida) и гены устойчивости к Y-вирусу $R y_{c h c}$ и $R y_{\text {sto }}$. Проведенная многолетняя оценка устойчивости коллекционных образцов картофеля к грибным болезням, вызываемым Phytophthora infestans (Mont.) de Bary (фитофтороз), Alternaria solani (Ell. et Mart.) Sor. (альтернариоз), Fusarium oxysporum Schlecht. (фузариозное увядание), Rhizoctonia solani J.G. Kühn (ризоктониоз) и Actinomyces scabies Gussow (парша обыкновенная) показала относительную устойчивость (7-9 баллов) у всех выделившихся гибридов.

Ключевые слова: Solanum tuberosum L., картофель, урожайность, адаптивная способность, взаимодействиие генотип ×среда, пластичность, стабильность.

Картофель (Solanum tuberosum L.) - одна из важнейших продовольственных культур, которая выращивается более чем в ста странах, четвертая по значению продовольственная культура мира и первая незерновая $(1,2)$. Преимущество картофеля заключается в способности формировать урожайность в широком спектре агросистем и в высоком удельном производстве сухой массы пищевого продукта на единицу возделываемой площади (3). Все большее внимание уделяется картофелю как к источнику не только углеводов, но и витаминов, минералов, пищевых волокон (4). Этим

* Работа выполнена в рамках КПНИ «Развитие селекции и семеноводства картофеля». 
обусловлен постоянный интерес к исследованиям по улучшению пищевых характеристик картофеля и повышению его устойчивости к биотическим и абиотическим факторам среды (5).

Обеспеченность теплом и влагой существенно влияет на растения картофеля как во время их активного роста, так и в период клубнеобразования $(6,7)$. Засуха - один из главных факторов, препятствующих росту растений и снижающих продуктивность наземных экосистем во многих регионах мира (8). В связи с проблемой глобального потепления необходимы меры, обеспечивающие адаптацию культур в этих условиях, в том числе создание новых генотипов с механизмами защиты от стрессов (9).

Не менее актуально повышение устойчивости картофеля к наиболее вредоносным и повсеместно распространенным болезням - фитофторозу, вирусам, картофельной цистообразующей нематоде, альтернариозу, ризоктониозу, бактериальным гнилям (10). Успех в выведении сортов, обеспечивающих комплексную защиту от патогенов, во многом зависит от подбора и систематизации исходных форм, мобилизации в селекционных программах культурных и дикорастущих видов Solanum - источников устойчивости и создания на их основе эффективных доноров (11). Молекулярные маркеры, тесно сцепленные с генами устойчивости, значительно интенсифицируют поиск ценных образцов благодаря существенному расширению выборки тестируемого материала и одновременному отбору генотипов с комплексом олигогенов (12), что значительно сокращает время создания новых форм.

Наличие генетического разнообразия в коллекции позволяет оценивать степень проявления основных хозяйственно ценных признаков в конкретных почвенно-климатических условиях и выделить наиболее селекционно ценные источники $(13,14)$. Фактически создание сорта предполагает не только получение и отбор новых генотипов, но и выявление экологической ниши, где эти генотипы обеспечат высокую продуктивность, экологическую стабильность и качество продукции (15).

Жесткие агроклиматические условия среды, эпифитотии фитофтороза в 1800-х годах, вирусные болезни, распространяющиеся в процессе размножения, уменьшили генетическое разнообразие культурных сортов картофеля $(16,17)$, в связи с чем исследователями и селекционерами во всем мире ведется активный поиск перспективных источников хозяйственно ценных свойств среди среди клубнеобразующих видов рода Solanum L., относящего к секции Petota (18).

В представленном исследовании среди полученных нами гибридных форм картофеля мы выявили образцы, обладающие в почвенно-климатических условиях сибирского региона высокой урожайностью, устойчивостью к неблагоприятным факторам среды и комплексной относительной устойчивостью к грибным болезням, Ү-вирусу картофеля и золотистой картофельной нематоде. Эти образцы уже включены в программы по созданию высокопродуктивных сортов картофеля с высокими адаптивными свойствами.

Цель работы - оценить исходный материал картофеля по адаптивности в эколого-географических условиях Западной Сибири.

Методика. Эксперименты были выполнены в зоне северной лесостепи Западной Сибири (Кузнецкая котловина, Кемеровский р-н, Кемеровская обл.) в 2014-2018 годах, различающихся по метеоусловиям (2014 и 2016 годы - наиболее неблагоприятные, с недостаточным количеством осадков в начале вегетации и высокими температурами в сочетании с переувлажнением в период образования клубней; 2015, 2017 и 2018 годы - с более благоприятным гидротермическим режимом в период вегетации при 
достаточном увлажнении и умеренных температурах).

Изучили свойства 170 образцов в коллекционном питомнике, в том числе гибриды картофеля (Solanum tuberosum L.), созданные в Кемеровском НИИ сельского хозяйства. В качестве стандарта использовали сорта Любава (ранний), Невский (среднеранний), Тулеевский (среднеспелый).

Посадку проводили в III декаде мая картофелесажалкой Cramer («CRAMER Technik», Германия) с нормой 35,0 тыс/кустов на 1 га, схема посадки $70 \times 35$ см. Общая площадь делянки $-70 \mathrm{~m}^{2}$, учетная $-20 \mathrm{~m}^{2}$; повторность 4-кратная, варианты размещали рендомизированно. Предшественник - чистый пар, почва - чернозем выщелоченный тяжелосуглинистый по гранулометрическому составу. Содержание в почве гумуса 8,52 \%, $\mathrm{N}-\mathrm{NO}_{3}-25,0$ мг/кг, $\mathrm{P}_{2} \mathrm{O}_{5}-140 \mathrm{мг} / \mathrm{кг}, \mathrm{K}_{2} \mathrm{O} 80 \mathrm{мг} / \mathrm{кг}(\mathrm{pH} \mathrm{6,1).}$

Описание и оценку морфологических, хозяйственных признаков проводили согласно методическим указаниям (19). Устойчивость растений к грибным болезням и к вирусам оценивали визуально по 9-балльной шкале $(1-$ очень низкая, 3 - низкая, 5 - средняя, 7 - высокая, 9 очень высокая) в полевых условиях на естественном фоне согласно Международному классификатору СЭВ видов картофеля секции Tuberarium (Dun.) Buk. рода Solanum L. (20) и методическим указаниям по изучению и поддержанию образцов мировой коллекции картофеля ВИР (21).

Параметры экологической пластичности $\left(\mathrm{b}_{\mathrm{i}}\right)$, стабильности $\left(\mathrm{Si}^{2}\right)$, индекс условий среды $\left(\mathrm{I}_{\mathrm{j}}\right)$ рассчитывали по S.A. Eberchart и W.A. Russel (22) на основе оценки положительного отклика генотипа на улучшение условий выращивания.

Наличие ДНК маркеров, сцепленных с генами устойчивости к Yвирусу картофеля ( $R y_{a d g}, R y_{c h c}, R y_{s t o}$, маркеры RYSC3, Ry186, YES3-3A) (2325), золотистой нематоде Globodera rostochiensis (Woll.) подтипов Rol, Ro4 (H1 и Gro 1-4, маркеры TG689, 57R, N195, Gro1-4-1) (11, 26, 27) и бледной картофельной нематоде Globodera pallida (Stone) Behrens подтипа Pa2 (Gpa2, маркер Gpa2-2) (11) выявляли методом мультиплексного классического ПЦР-анализа. ДНК выделяли из 200 мг ткани клубня, используя набор ГМО-МагноСорб (ЗАО «Синтол», Россия). Навеску ткани измельчали в гомогенизаторе Precellys 24 («Bertin Corp.», США) с добавлением 800 мкл лизирующего буфера из указанного набора. Полученный гомогенат переносили в пробирку объемом 2 мл. Далее проводили выделение с помощью роботизированной станции Савраска 02 (ООО «Синтол», Россия) в соответствии с протоколом производителя. Амплификацию выполняли в мультиплексе с использованием 2,5× реакционной смеси для ПЦР M428 (OOO «Синтол», Россия). Реакционная смесь (25 мкл) содержала 10× буфер для Таq ДНК-полимеразы (ЗАО «Синтол», Россия), 2,5 мМ смесь dNTP («Евроген», Россия), 25 мМ водный раствор хлорида магния («Fermentas», Латвия), 5-10 пкмоль каждого праймера (ЗАО «Синтол», Россия), 0,5 е.а. Таq ДНК-полимеразы (ЗАО «Синтол», Россия), 10 нг анализируемой ДНК и 10-13 мкл автоклавированной бидистиллированной воды. Использовали описанные праймеры (28) и оптимизировали режимы при валидационных испытаниях в единую циклограмму (12): 10 мин при $94{ }^{\circ} \mathrm{C} ; 30$ с при $94{ }^{\circ} \mathrm{C}$, 30 с при $68{ }^{\circ} \mathrm{C}, 30$ с при $72^{\circ} \mathrm{C}\left(5\right.$ циклов); 30 с при $94{ }^{\circ} \mathrm{C}, 30$ с при $58{ }^{\circ} \mathrm{C}$, 30 с при $72{ }^{\circ} \mathrm{C}\left(35\right.$ циклов); 30 с при $94^{\circ} \mathrm{C}, 5$ мин при $72{ }^{\circ} \mathrm{C}$. Амплификацию фрагментов перед секвенированием проводили по следующему протоколу: 10 мин при $94{ }^{\circ} \mathrm{C}$; 30 с при $94{ }^{\circ} \mathrm{C}, 30$ с при $68{ }^{\circ} \mathrm{C}, 1,5$ мин с при $72{ }^{\circ} \mathrm{C}$ (5 циклов); 30 с при $94{ }^{\circ} \mathrm{C}$, 30 с при $58{ }^{\circ} \mathrm{C}, 1,5$ мин при $72{ }^{\circ} \mathrm{C}(35$ циклов); 30 с при $94{ }^{\circ} \mathrm{C}, 5$ мин при $72{ }^{\circ} \mathrm{C}$. Мультиплексную ПЦР по восьми маркерам выполняли, используя Applied Biosystems 2720 Thermal Cycler 
(«Thermo Fisher Scientific», США). Продукты амплификации исследовали с помощью секвенатора Нанофор 05 (Институт аналитического приборостроения РАН, Россия). Прямые праймеры помечали флуоресцентными красителями 6FAM или 5R6G (ОOO «Синтол», Россия). Полученные результаты оценивали с помощью программы «ДНК Фрагментный анализ» (ИАП РАН, Россия) (29).

Статистическую обработку данных проводили в программе Snedecor (разработчик О.Д. Сорокин, Россия) методами вариационного и дисперсионного анализов $(30,31)$. Рассчитывали средние $(M)$, стандартные отклонения $( \pm \mathrm{SD})$ и коэффициенты вариации $(C v, \%)$ сравниваемых показателей по урожайности. При дисперсионном анализе использовали критерии оценки $F$-Фишера на 5 \% уровне значимости, определяли средние $(M)$ и их стандартные ошибки $( \pm \mathrm{SEM})$, долю влияния факторов в общей дисперсии признака ( $\mathrm{q}_{\mathrm{v}}^{2}$, squared factor loading). Рассчитывали наименьшую существенную разность на $5 \%$ уровне значимости $\left(\mathrm{HCP}_{05}\right)$.

Результаты. За очень длительный период изучения диких клубненосных растений секции Tuberarium рода Solanum выявлены источники устойчивости к широкому кругу вредных организмов (грибы и оомицеты, бактерии, вирусы, нематоды) и к неблагоприятным факторам среды (заморозки, повышенные температуры, засуха), так как в естественных условиях существует давление естественного отбора $(32,33)$.

В наших исследованиях для создания ценных источников устойчивости к вредным организмам в гибридизацию включали сорта и межвидовые гибриды картофеля из коллекции ВИР: Mors (Z77. 1/24 × III.74.562/3 N) - устойчив к раку, золотистой картофельной нематоде, относительно устойчив к вирусным болезням; Пост 86 (П77196/190 × Полесский розовый) - устойчив к раку, среднеустойчив к парше, бактериальным гнилям, фитофторозу; гибрид 89-1-12 \{Приекульский ранний $\times$ [Wilja $\times(S$. andigenum US-W $1793 \times S$. rubinii $\mathrm{k}-2890-4)]\} \times\{[[$ Primerosa $\times(S$. andigenum US$\mathrm{W} 1793 \times S$. rubinii k-2890-4)] $\times($ Suna $\times$ S. stoloniferum k-2490-5)] $\times(S$. demissum k-1539 $\times$ S. vernei D 459) $\}$ - устойчив к фитофторозу, нематоде, вирусам Х и Y; Sagitta [Schwalbe $\times($ S.adg. 54/3/14 $\times$ Oberarnbacher Frahe)] устойчив к раку, к картофельной нематоде (Rol), к вирусу X; Baszta (PW $31 \times$ Granola) - устойчив к раку, к золотистой картофельной нематоде, относительно устойчив в полевых условиях к фитофторозу, паршой обыкновенной поражается слабо, устойчив к вирусу Ү. Всего испытывали 19 гибридов, полученных Кемеровском НИИСХ в 2014-2018 годах (депонированы в коллекцию института), со следующими родословными: 27-7c-11, 12-7c-11 - Любава $\times$ Mors; 22103-10 - Лазарь $\times$ 89-1-12; 175-10 - Альпинист $\times$ Adretta; 5-20c-12, 9-20c-12 - Никулинский $\times$ Белорусский 3; 1-512 - Лазарь $\times$ Karlena; 15-13c-11 - Удалец $\times$ Гранат; 9-14-12, 141-13 Накра $\times$ смесь пыльцы (сорт Удача $+180-1+89-1-12)$; 11-13 - Никулинский $\times$ Karlena; 81-13 - Любава $\times$ Sagitta; 161-13 - Зарево $\times$ Karlena; 8413 - Любава $\times$ Sagitta; 6-14-11 - Тулеевский $\times$ Пост 86; 3-21c-11 - Тулеевский $\times$ Mors; 3-11-11 - Bora valley $\times$ Аврора; 1615-10 - Невский $\times$ Жуковский ранний; 17-5/6-11 - Baszta $\times$ 89-1-12. Использование в селекционном процессе межвидовых гибридов картофеля позволяет получить формы и сорта с устойчивостью к бактериальным болезням, фитофторозу, нематодам, вирусам (34).

Оценка гибридов картофеля по устойчивости к болезням в полевых условиях. Согласно Международному классификатору СЭВ видов картофеля секции Tuberarium (Dun.) Buk. рода Solanum L. (20), использованная нами шкала применяется для обобщенной оценки много- 
летних данных полевой устойчивости селекционного материала. Мы отмечали ежегодное поражение растений болезнями в полевых условиях (селекционные питомники) на естественном фоне, 2014 и 2016 годы были годами развития эпифитотий, чему способствовали высокие температуры в сочетании с переувлажнением во второй период вегетации.

По результатам многолетней визуальной оценки поражения растений грибными болезнями, вызываемым Phytophthora infestans (Mont.) de Bary (фитофтороз), Alternaria solani (Ell. et Mart.) Sor. (альтернариоз), Fusarium oxysporum Schlecht. (фузариозное увядание), Rhizoctonia solani J.G. Kühn (ризоктониоз) и Actinomyces scabies Gussow (парша обыкновенная) (18), селекционную ценность представляют образцы с комплексной устойчивостью от 7 баллов и выше (табл. 1). Высокой и очень высокой устойчивостью к грибным болезням (7-9 баллов) в среднем за годы испытаний в полевых условиях выделились гибриды картофеля 3-21с-11, 1615-10, 6$14-11,22103-10,17-5 / 6-11,1-5-12,27-7 \mathrm{c}-11,12-7 \mathrm{c}-11,175-10,5-20 \mathrm{c}-12$, 920c-1, 15-13c-11, 9-14-12, 141-13, 81-13, 161-13, 84-13, 3-11-11 и сортастандарты Любава, Тулеевский, Невский. Высокую и очень высокую устойчивость клубней к фитофторозу, ризоктониозу и парше обыкновенной проявили все представленные в таблице 1 образцы, за исключением гибрида 11-13 (комбинация Никулинский $\times$ Karlena) со средней устойчивостью к ризоктониозу.

1. Средняя оценка гибридов картофеля (Solanum L.) по устойчивости к болезням в сравнении с сортами-стандартами (st) (Кемеровская обл., 2014-2018 годы, естественный инфекционный фон)

\begin{tabular}{|c|c|c|c|c|c|c|c|c|}
\hline \multirow[b]{2}{*}{ Сорт, гибрид } & \multirow[b]{2}{*}{ Происхождение } & \multicolumn{7}{|c|}{ Устойчивость к болезням, балл } \\
\hline & & 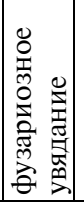 & 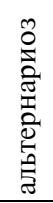 & 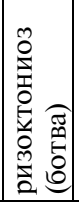 & 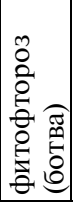 & 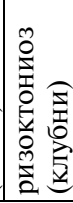 & 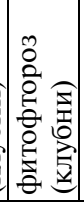 & 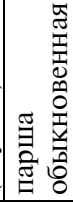 \\
\hline \multicolumn{2}{|l|}{ Любава (st) } & 9 & 9 & 9 & 7 & 7 & 9 & 7 \\
\hline \multicolumn{2}{|l|}{ Невский (st) } & 9 & 9 & 9 & 8 & 7 & 9 & 9 \\
\hline \multicolumn{2}{|l|}{ Тулеевский (st) } & 9 & 9 & 8 & 7 & 7 & 9 & 8 \\
\hline $3-21 c-11$ & Тулеевский $\times$ Mors & 9 & 9 & 9 & 6 & 7 & 9 & 8 \\
\hline $1615-10$ & Невский $\times$ Жуковский ранний & 9 & 9 & 9 & 6 & 7 & 9 & 9 \\
\hline $6-14-11$ & Тулеевский × Пост 86 & 9 & 8 & 9 & 6 & 7 & 9 & 8 \\
\hline $22103-10$ & Лазарь $\times$ 89-1-12 & 9 & 9 & 8 & 8 & 7 & 9 & 9 \\
\hline $17-5 / 6-11$ & Baszta $\times 89-1-12$ & 9 & 9 & 8 & 8 & 9 & 9 & 8 \\
\hline $1-5-12$ & Лазарь $\times$ Karlena & 9 & 8 & 8 & 8 & 7 & 9 & 8 \\
\hline $27-7 \mathrm{c}-11$ & Любава × Mors & 8 & 8 & 9 & 8 & 7 & 9 & 9 \\
\hline $12-7 c-11$ & Любава $\times$ Mors & 9 & 9 & 8 & 8 & 8 & 9 & 8 \\
\hline $175-10$ & Альпинист $\times$ Adretta & 8 & 9 & 9 & 8 & 7 & 9 & 8 \\
\hline $5-20 c-12$ & Никуленский $\times$ Белорусский 3 & 9 & 9 & 9 & 7 & 7 & 9 & 8 \\
\hline $15-13 c-11$ & Удалец $\times$ Гранат & 8 & 9 & 7 & 8 & 7 & 9 & 8 \\
\hline $9-20 c-12$ & Никуленский $\times$ Белорусский 3 & 9 & 9 & 9 & 7 & 7 & 9 & 8 \\
\hline $9-14-12$ & Накра $\times$ смесь пыльцы (Удача $+180-1+89-1-12)$ & 9 & 9 & 9 & 8 & 9 & 9 & 8 \\
\hline $141-13$ & Накра $\times$ смесь пыльцы (Удача $+180-1+89-1-12)$ & 9 & 9 & 9 & 8 & 7 & 9 & 8 \\
\hline $11-13$ & Никуленский $\times$ Karlena & 9 & 9 & 9 & 8 & 5 & 9 & 8 \\
\hline $81-13$ & Любава $\times$ Sagitta & 9 & 9 & 9 & 8 & 8 & 9 & 9 \\
\hline $161-13$ & Зарево $\times$ Karlena & 9 & 9 & 8 & 8 & 9 & 9 & 9 \\
\hline $84-13$ & Любава $\times$ Sagitta & 8 & 8 & 7 & 7 & 7 & 9 & 8 \\
\hline $3-11-11$ & Bora valley $\times$ Аврора & 9 & 9 & 7 & 7 & 9 & 9 & 7 \\
\hline
\end{tabular}

П р и м е ч а н и е. Фитофтороз - возбудитель Phytophthora infestans (Mont.) de Bary (фитофтороз), альтернариоз - Alternaria solani (Ell. et Mart.) Sor., фузариозное увядание - Fusarium oxysporum Schlecht., ризоктониоз - Rhizoctonia solani J.G. Kühn, парша обыкновенная - Actinomyces scabies Gussow.

Оценка гибридов картофеля по чувствительности к вирусным инфекциям и нематодам. Описано более 40 вирусов, заражающих картофель в естественных условиях (35), но наиболее опасным и распространенным считается Y-вирус (potato virus Y, PVY) $(36,37)$, значитель- 
ный вред также наносит X-вирус (potato virus X, PVX) $(38,39)$. ДНК маркеры, сцепленные с генами устойчивости к болезням и вредителям, позволяют существенно повысить эффективность отбора ценных генотипов на ранних этапах селекции (25) и значительно интенсифицировать их поиск (40-42). Новым подходом в применении ДНК маркеров служит технология мультиплексной ПЦР для одновременного тестирования сортов и селекционных линий картофеля по нескольким генам, контролирующим устойчивость к вирусам и нематодам $(11,43)$. Использованные в работе маркеры с указанием размера диагностического фрагмента представлены в таблице 2.

2. $\boldsymbol{R}$-гены и ассоциированные с ними ДНК маркеры, использованные для молекулярного скрининга полученных образцов картофеля (Solanum L.)

\begin{tabular}{|c|c|c|c|c|}
\hline Ген & Хромосома & Признак & $\begin{array}{l}\text { ДНК маркер (раз- } \\
\text { мер диагностиче- } \\
\text { ского фрагмента) }\end{array}$ & Ссылка \\
\hline$R y_{a d g}$ & $11-я$ & Иммунитет к Y-вирусу картофеля (PVY) & RYSC3 (321 п.н.) & (22) \\
\hline$R y_{\text {chc }}$ & 7-я & Иммунитет к PVY & Ry186 (587 п.н.) & (23) \\
\hline$R y_{\text {sto }}$ & $12-я$ & Иммунитет к PVY & YES3-3А (341 п.н.) & (24) \\
\hline$H 1$ & $5-я$ & Устойчивость к Globodera rostochiensis патотипов Ro1, Ro4 & TG689 (141 п.н.) & (25) \\
\hline$H 1$ & $5-9$ & Устойчивость к G. rostochiensis патотипов Ro1, Ro4 & 57R (452 п.н.) & (26) \\
\hline$H 1$ & $5-9$ & Устойчивость к G. rostochiensis патотипов Ro1, Ro4 & N195 (337 п.н.) & (11) \\
\hline Gro 1-4 & 7-я & Устойчивость к G. rostochiensis патотипов Ro1, Ro4 & Grol-4-1 (602 п.н.) & (11) \\
\hline Gpa2 & $12-я$ & Устойчивость к G. pallida патотипа Ра2 & Gpa2-2 (452 п.н.) & (11) \\
\hline
\end{tabular}

3. Наличие генов устойчивости к патогенам и вредителям у сортов-стандартов (st) и полученных гибридов картофеля (Solanum L.) по результатам молекулярной идентификации ДНК маркеров

\begin{tabular}{|c|c|c|c|c|c|c|c|c|c|c|c|}
\hline \multirow[b]{2}{*}{ Вредоносный агент } & \multirow[b]{2}{*}{$\begin{array}{l}\text { Ген устой- } \\
\text { чивости }\end{array}$} & \multirow[b]{2}{*}{ ДНК маркер } & \multicolumn{9}{|c|}{ Сорт, образец } \\
\hline & & & 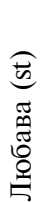 & 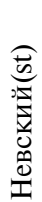 & 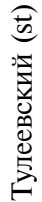 & 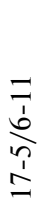 & $\begin{array}{l}\frac{0}{1} \\
\frac{1}{1} \\
b \\
b\end{array}$ & $\begin{array}{l}\bar{z} \\
\frac{1}{\sim} \\
\dot{c} \\
\end{array}$ & 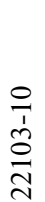 & $\frac{7}{\frac{1}{ \pm}}$ & $\frac{\sim}{1}$ \\
\hline \multirow[t]{3}{*}{ Y-вирус картофеля (PVY) } & $R y_{a d g}$ & RYSC3 & 0 & 0 & 0 & 0 & 0 & 0 & 0 & 0 & 0 \\
\hline & $R y_{c h c}$ & Ry 186 & 0 & 0 & 0 & + & 0 & 0 & 0 & 0 & + \\
\hline & $R y_{\text {sto }}$ & YES3-3A & 0 & 0 & 0 & 0 & 0 & + & + & 0 & + \\
\hline \multirow[t]{4}{*}{ Globodera rostochiensis } & $H 1$ & TG689 & 0 & 0 & 0 & + & 0 & + & + & 0 & + \\
\hline & & $57 \mathrm{R}$ & 0 & 0 & + & + & 0 & + & + & + & + \\
\hline & & N195 & 0 & 0 & + & + & 0 & + & + & + & + \\
\hline & Gro 1-4 & Gro1-4-1 & 0 & 0 & 0 & 0 & 0 & 0 & 0 & 0 & + \\
\hline G. pallida & Gра 2 & Gpa2-2 & 0 & 0 & 0 & 0 & 0 & + & + & 0 & + \\
\hline
\end{tabular}

Разрешающая способность капиллярного электрофореза достаточна для идентификации близких по длине фрагментов, в том числе за счет различающихся по спектру флуорофоров. Использованный в работе генетический анализатор (Нанофор 05) позволяет с высокой чувствительностью определить размер ампликона с точностью до нуклеотида. Проведенный нами молекулярно-генетический анализ выявил маркеры доминантных аллелей генов устойчивости к Y-вирусу картофеля $\left(R y_{c h c}\right)$ и золотистой картофельной нематоде $H 1$ (по трем маркерам - TG689, 57R и N195) у гибрида 17-5/6-11 (табл. 3). Кроме того, у образцов 22103-10 и 3-21с-11 мы показали наличие маркера YES3-3A, сцепленного с геном $R y_{\text {sto }}$, и маркеров TG689, 57R, N195, идентифицирующих ген $H 1$, а также маркеpa Gpa2-2 гена Gpa2 (см. табл. 3). Гибрид 1-5-12 нес комбинацию доминантных аллелей генов H1 (наличие всех трех маркеров), Gro 1-4 (контролирует устойчивость к $G$. rostochiensis), Gpa 2 (устойчивость к G. pallida), а также генов устойчивости к Ү-вирусу картофеля $R y_{c h c}$ и $R y_{s t o}$. В генотипе гибрида 6-14-11 мы обнаружили два маркера гена H1 (57 R и N 195), кон- 
тролирующего устойчивость к G. rostochiensis.

Оценка гибридов картофеля по урожайности, экологической пластичности и стабильности. Мы оценили урожайность и устойчивость к неблагоприятным факторам у гибридов 3-21с-11, 1615-10, 6-14-11, 22103-10, 17-5/6-11 и 1-5-12, выделившихся по комплексной устойчивости к Y-вирусу картофеля, золотистой картофельной нематоде и грибным болезням (табл. 4). Результаты показали, что доля влияния условий среды на урожайность картофеля составляет 55,9 \%, генотипа $-11,5 \%$.

4. Урожайность (т/га) полученных гибридов картофеля (Solanum L.) в зависимости от условий среды по годам испытаний в сравнении с сортами-стандартами (st) (Кемеровская обл.)

\begin{tabular}{|c|c|c|c|c|c|c|c|c|c|}
\hline \multirow{2}{*}{ Сорт, гибрид } & \multicolumn{5}{|c|}{ Год испытания } & \multirow{2}{*}{ Yj } & \multirow{2}{*}{$C v, \%$} & \multirow[b]{2}{*}{$b_{i}$} & \multirow{2}{*}{$\mathrm{S}_{\mathrm{i}}^{2}$} \\
\hline & 2014 & 2015 & 2016 & 2017 & 2018 & & & & \\
\hline \multicolumn{10}{|c|}{ Ранняя группа спелости } \\
\hline Любава (st) & 16,7 & 12,4 & 17,7 & 20,0 & 24,2 & 18,2 & 23,9 & 0,81 & 26,2 \\
\hline $3-21 c-11$ & 25,2 & 12,7 & 20,7 & 22,3 & 32,3 & 22,6 & 31,4 & 1,53 & 14,6 \\
\hline $1615-10$ & 22,4 & 12,8 & 21,6 & 21,2 & 27,6 & 21,1 & 25,2 & 1,17 & 5,2 \\
\hline $6-14-11$ & 30,4 & 15,9 & 24,7 & 20,0 & 22,3 & 22,7 & 23,9 & 0,91 & 26,9 \\
\hline \multicolumn{10}{|c|}{ Среднеранняя группа спелости } \\
\hline Невский (st) & 26,3 & 15,0 & 22,8 & 21,7 & 22,8 & 21,7 & 19,0 & 0,88 & 4,4 \\
\hline $17-5 / 6-11$ & 28,3 & 15,3 & 26,1 & 26,1 & 31,1 & 25,4 & 23,6 & 1,38 & 1,1 \\
\hline \multicolumn{10}{|c|}{ Среднеспелая группа } \\
\hline Тулеевский (st) & 13,8 & 15,3 & 19,7 & 20,3 & 21,1 & 18,0 & 18,1 & 0,28 & 18,4 \\
\hline 22103-10 & 30,1 & 16,4 & 24,7 & 26,6 & 20,8 & 23,7 & 22,3 & 0,84 & 25,8 \\
\hline $1-5-12$ & 27,8 & 13,9 & 18,5 & 23,1 & 25,8 & 21,8 & 25,8 & 1,20 & 9,4 \\
\hline$\sum \mathrm{x}_{\mathrm{ij}}$ & 221,0 & 129,7 & 196,5 & 201,3 & 228,0 & 976,5 & & & \\
\hline $\mathrm{x}_{\mathrm{j}}$ & 24,6 & 14,4 & 21,8 & 22,4 & 25,3 & 21,7 & & & \\
\hline $\mathrm{HCP}_{05}$ & \multicolumn{9}{|c|}{4,1} \\
\hline \multicolumn{10}{|c|}{$\begin{array}{l}\text { Пр и м е ч а н и е. } C v-\text { коэффициент вариации признака, } \mathrm{Y}_{\mathrm{j}}-\text { средняя урожайность сорта в ј-й год ис- } \\
\text { пытания, } \mathrm{b}_{\mathrm{i}}-\text { коэффициент регрессии, } \mathrm{S}_{\mathrm{i}}{ }^{2}-\text { коэффициент стабильности, } \Sigma \mathrm{x}_{\mathrm{ij}}-\text { сумма урожаев всех сор- } \\
\text { тов в } \mathrm{j} \text {-й год испытания, } \mathrm{x}_{\mathrm{j}}-\text { средняя урожайность всех сортов в } \mathrm{j} \text {-й год испытания. }\end{array}$} \\
\hline
\end{tabular}

Считается, что картофель ( $S$. tuberosum) весьма чувствителен к сочетанию повышенных температур с дефицитом осадков. Участившие засухи ставят под угрозу устойчивое производство этой культуры, поэтому во всем мире активно изучается сложная фенотипическая реакция растений картофеля на засуху $(44,45)$ и генетические основы его толерантности к таким условиям (46). Реакция растений на влагообеспеченность определяется как их биологическими особенностями, так и другими факторами. В том числе она зависит от взаимодействия «генотип $\times$ среда», в результате которого проявляется защитная реакция на уровне функций устьичного аппарата листа (47). Мы сравнили индексы условий среды $\left(\mathrm{I}_{\mathrm{j}}\right)$ по годам исследований, чтобы охарактеризовать экологические факторы, на фоне которых оценивались полученные генотипы. В 2014, 2015, 2016, 2017 и 2018 году величина $\mathrm{I}_{\mathrm{j}}$ составил соответственно 2,9; -7,3; 0,1;0,7 и 3,6.

По результатам проведенных расчетов, условия, которые можно считать наиболее благоприятными, сложились в 2014 и в 2018 году. В эти годы была получена наибольшая урожайность в среднем по опыту - coответственно 24,6 и 25,3 т/га. В 2014 году наибольшую урожайность имели гибриды 22103-10 (среднеспелая группа, 30,1 т/га, что на 16,4 т/га выше, чем показатель у сорта-стандарта Тулеевский - 13,8 т/га), а также 6-14-11 (ранняя группа спелости, 30,4 т/га, что превышает урожайность сортастандарта Любава на 13,7 т/га). В группе раннеспелых достоверное увеличение урожайности относительно стандарта демонстрировали гибриды 1615-10 (на 5,7 т/га) и 3-21с-11 (на 8,5 т/га) $\left(\mathrm{HCP}_{05}=0,77 \mathrm{~T} / г а\right)$. У среднеспелого гибрида 1-5-12 урожайность в 2014 году была почти в 2 раза выше $(27,8$ т/га), чем у сорта-стандарта Тулеевский. В 2018 году при $\mathrm{HCP}_{05}=1,0$ т/га самими 
высокопродуктивными были гибриды 1-5-12 (25,8 т/га, сорт-стандарт Тулеевский - 21,1 т/га), 17-5/6-11 (31,1 т/га, сорт-стандарт Невский - 22,8 т/га) и 3-21c-11 (32,3 т/га, сорт-стандарт Любава - 24,2 т/га). Все выделившиеся гибриды в годы с благоприятными условиями вегетации превосходили по урожайности стандарты по средним показателям за 5 лет (превышение от 16,0 до $31,5 \%)$. Вариабельность урожайности $(C v)$ по сортам и гибридам составила от 18,1 до 31,4 \%, наименьшую изменчивость признака в целом по опыту имел сорт Тулеевский, что свидетельствует о его пластичности и стабильности, наибольшую - гибрид 3-21с-11.

Растения картофеля взаимодействуют как с абиотическими, так и с биотическими факторами. В результате влияния комбинации факторов метаболизм изменяется иначе, чем при реакции на каждый фактор по отдельности (что дополнительно зависит как от характера воздействия, так и от биологических особенностей генотипа), поскольку молекулярные сигнальные пути, контролирующие абиотические и биотические напряжения, могут проявлять как синергизм, так и антагонизм. Абиотические напряжения усугубляют стресс у растений и могут вызывать повреждение клеток, что негативно влияет на урожайность картофеля, качество и рыночную стоимость клубней $(7,48)$.

Зависимость урожайности сортов и гибридов картофеля от внешних условий среды мы оценили по коэффициенту регрессии $b_{i}$ (пластичность) и коэффициенту стабильности $\mathrm{S}_{\mathrm{i}}{ }^{2}$ (стабильность, связанная с дисперсией отклонений признака у каждого образца от линии регрессии). Расчеты показали низкую пластичность $\left(b_{i}<1\right)$ у сортов Любава $\left(b_{i}=0,81\right)$, Невский $\left(b_{i}=0,88\right)$ и Тулеевский $\left(b_{i}=0,28\right)$. Они слабо реагируют на условия выращивания, что присуще экстенсивным генотипам. Среди экстенсивных сортов Невский проявил высокую стабильность $\left(\mathrm{S}_{\mathrm{i}}{ }^{2}=4,43\right)$, что гарантирует ежегодный урожай. В группу экстенсивных генотипов были также отнесены гибриды 6-4-11 $\left(b_{i}=0,91\right)$ и 22103-10 $\left(b_{i}=0,84\right)$. По показателю пластичности $\left(\mathrm{b}_{\mathrm{i}}>1\right)$ выделился гибрид 3-21c-11 $\left(\mathrm{b}_{\mathrm{i}}=1,53\right)$. Он относится к интенсивному типу, так как характеризуется высокой реакцией на условия выращивания. Гибрид 3-21c-11 мы отнесли к генотипам со средней стабильностью по урожайности $\left(\mathrm{S}_{\mathrm{i}}{ }^{2}=14,6\right)$.

Наибольшую ценность представляют гибриды, у которых $b_{i}>1$, тогда как $\mathrm{S}_{\mathrm{i}}{ }^{2}$ (коэффициент стабильности) стремится к нулю. Среди изученных генотипов гибрид 17-5/6-11 формировал наиболее стабильный урожай $\left(\mathrm{S}_{\mathrm{i}}{ }^{2}=1,1\right)$ при том, что его отзывчивость на условия выращивания была высокой $\left(b_{i}=1,38\right)$. В группу интенсивных генотипов с высокой стабильностью урожайности выделились гибриды 1615-10 ( $\left.\mathrm{b}_{\mathrm{i}}=1,17, \mathrm{~S}_{\mathrm{i}}{ }^{2}=5,2\right)$ и 1-5-12 ( $\left.\mathrm{b}_{\mathrm{i}}=1,20, \mathrm{~S}_{\mathrm{i}}^{2}=9,4\right)$.

Таким образом, при изучении коллекционных образцов картофеля выделены генотипы экстенсивного типа: сорта Любава $\left(b_{i}=0,81\right)$, Невский $\left(b_{\mathrm{i}}=0,88\right)$, Тулеевский $\left(\mathrm{b}_{\mathrm{i}}=0,28\right)$, гибриды 6-4-11 $\left(\mathrm{b}_{\mathrm{i}}=0,91\right), 22103-10$ $\left(b_{i}=0,84\right)$. К группе генотипов интенсивного типа со средней стабильностью урожайности отнесен гибрид 3-21c-11 $\left(\mathrm{b}_{\mathrm{i}}=1,53 ; \mathrm{S}_{\mathrm{i}}{ }^{2}=14,6\right)$. Наибольшую ценность представляют генотипы картофеля интенсивного типа с повышенной экологической пластичностью и повышенной стабильностью урожайности - гибриды 17-5/6-11 $\left(\mathrm{b}_{\mathrm{i}}=1,38 ; \mathrm{S}_{\mathrm{i}}{ }^{2}=1,1\right), 1615-10\left(\mathrm{~b}_{\mathrm{i}}=1,17\right.$; $\left.\mathrm{Si}^{2}=5,2\right)$ и 1-5-12 ( $\left.\mathrm{b}_{\mathrm{i}}=1,20 ; \mathrm{S}_{\mathrm{i}}{ }^{2}=9,4\right)$. Все гибриды как экстенсивного, так и интенсивного типа, выделившиеся по показателям экологической пластичности и стабильности, относительно устойчивы (7-9 баллов) к грибным 
болезням - фитофторозу, альтернариозу, фузариозному увяданию, ризоктониозу и парше обыкновенной. Гибрид 17-5/6-11 является донором устойчивости к Y-вирусу картофеля (ген $R y_{c h c}$ ) и золотистой картофельной нематоде (ген $H 1$ выявлен по трем маркерам - TG689, 57R, N195). Донорами устойчивости к Ү-вирусу картофеля (ген $R y_{c h c}$ ), золотистой картофельной нематоде (ген H1) и бледной нематоде (ген Gpa 2) могут быть гибриды 22103-10 и 3-21c-11. В генотипе гибрида 1-5-12 сочетаются доминантные аллели генов H1, Grol-4 (контролируют устойчивость к золотистой картофельной нематоде), гена Gpa2 (определяет устойчивость к бледной нематоде), а также генов устойчивости к Ү-вирусу картофеля $R y_{c h c}$ и $R y_{\text {sto }}$.

\author{
Кемеровский НИИ сельского хозяйства - филиал \\ ФГБУН Сибирский федеральный научный центр \\ агробиотехнологий РАН, \\ 650510 Россия, Кемеровская обл., Кемеровский р-н, п. Новостройка, \\ ул. Центральная, 47, \\ e-mail: vpakyl@mail.ru $\bowtie$, nik.lapshinov.55@mail.ru,kemniish@mail.ru, \\ kulikova.potato@yandex.ru
}

Поступила в редакцию

Sel'skokhozyaistvennaya biologiya [Agricultural Biology], 2019, V. 54, № 5, pp. 978-989

\title{
DONORS OF POTATO (Solanum L.) PLASTICITY AND YIELD STABILITY TRAITS IN THE ENVIRONMENTAL CONDITIONS OF NORTH FOREST STEPPE OF WESTERN SIBERIA
}

\author{
V.N. Pakul, N.A. Lapshinov, A.N. Gantimurova, V.I. Kulikova
}

\begin{abstract}
Kemerovo Research Institute of Agriculture, the Branch of Siberian Federal Scientific Center of Agrobiotechnology RAS, 47, ul. Tsentral'naya, p. Novostroika, Kemerovo District, Kemerovo Province, 650510 Russia, e-mail vpakyl@mail.ru ( $\triangle$ corresponding author), nik.lapshinov.55@mail.ru, kemniish@mail.ru, kulikova.potato@yandex.ru ORCID:

Pakul V.N. orcid.org/0000-0003-0681-6273

Lapshinov N.A. orcid.org/0000-00019869-2372

Gantimurova A.N. orcid.org/0000-0002-2945-6381

Kulikova V.I. orcid.org/0000-0002-6204-7555
\end{abstract}

The authors declare no conflict of interests

Acknowledgements:

This work was carried out as part of the Complex Program of Research "Development of potato breeding and seed production".

Received September 28, 2019

doi: 10.15389/agrobiology.2019.5.978eng

\section{Abstract}

Potato (Solanum tuberosum L.) varieties possessing sustainable high yield under varying environmental conditions and other valuable properties, e.g. resistance to diseases and pests, are much appreciated by practitioners. Seeking for donor plants with high environmental plasticity and stability in specific cultivation zone is a key point, especially in creating highly productive adaptive varieties for regions with severe agro-climatic conditions. This paper reports the first assessment of new potato hybrids created in the soil and climatic conditions of Western Siberia, as donors of high yielding and complex relative resistance to fungal diseases, potato Y-virus, and golden potato nematode. The best of them are already involved in practical selection for productivity and high adaptability. Our goal was to assess the parameters of adaptability in created potato hybrids under the conditions of the northern forest-steppe of Western Siberia (Kuznetsk Basin, Kemerovo Region, Kemerovo District, 2014-2018; $70 \mathrm{~m}^{2}$ plots with $20 \mathrm{~m}^{2}$ test area arranged randomly in four repetitions). Planting was carried out in the third decade of May at 35.0 thousand bushes per 1 ha $(70 \times 35 \mathrm{~cm}$; a Cramer potato planter, CRAMER Technik, Germany). The samples $(n=170)$ including collection potato hybrids created in Kemerovo Research Institute of Agriculture were examined in a collection nursery. The varieties Lyubava (early season), Nevskii (medium-early ripening) and Tuleevskii (mediumripening) were the standard. According to our research data, the Lyubava, Nevskii, Tuleevskii varieties and hybrids 6-4-11 and 22103-10 are extensive type potato genotypes with low environmental plasticity $\left(b_{i}=0.28-0.91<1\right)$. Hybrid $3-21 s-11\left(b_{i}=1.53\right)$ with medium yield stability $\left(S_{i}{ }^{2}=14.6\right)$ showes the greatest response to external conditions. Hybrids 22103-10 and 3-21c-11 are donors of resistance to potato virus Y (gene $R y_{c h c}$ ), golden potato nematode Globodera rostochiensis (Woll.) (gene H1) and pale nematode G. pallida (Stone) Behrens. (gene Gpa2). According to a complex of the traits, three hybrids of the intensive type (17-5/6-11, 1-5-12 and 1615-10) possess high adaptiveness, i.e. an increased environmental plasticity $\left(b_{i}=1.38,1.20\right.$, and 1.17$)$ and high stability $\left(\mathrm{S}_{\mathrm{i}}^{2}=1.1\right.$, 
9.4, 5.2), and are of particular value for breeding. Moreover, the hybrid 17-5/6-11 is a donor of resistance genes to potato virus Y (PVY) $\left(R y_{c h c}\right)$ and golden potato nematode $(H 1$, with three markers TG689, 57R, and N195). Hybrid 1-5-12 contains a combination of the $H 1$ genes (for all three markers) and Gro 1-4 gene of resistance to G. rostochiensis, Gpa2 gene of resistance to G. pallida, and genes $R y_{c h c}$ and $R y_{\text {sto }}$ conferring resistance to PVY. Long-term field surveys of resistance to fungal pathogens, Phytophthora infestans (Mont.) De Bary, Alternaria solani (Ell.Et Matr) Sor., Fusarium oxysporum Schlet., Rhizoctonia solani J.G. Kühn) and Actinomyces scabies Gussow showed a 7-9 point relative stability in all tested hybrids.

Keywords: Solanum tuberosum L., potato, yields, adaptability, genotype $\times$ environment interaction, plasticity, stability.

\section{REFEREN CES}

1. Jacobs M.M.J., Smulders M.J.M., van den Berg R.G., Vosman B. What's in a name: genetic structure in Solanum section Petota studied using population-genetic tools. BMC Evolutionary Biology, 2011, 11: 42 (doi: 10.1186/1471-2148-11-42).

2. Jansky S.H., Dempewolf H., Camadro E.L., Simon R., Zimnoch-Guzowska E., Risognin D.A., Bonierbale M.A. Case for crop wild relative preservation and use in potato. Crop Science, 2013, 53: 746-754 (doi: 10.2135/cropsci2012.11.0627).

3. Devaux A., Kromann P., Ortiz O. Potatoes for sustainable global food security. Potato Res., 2014, 57(3-4): 185-199 (doi: 10.1007/s11540-014-9265-1).

4. Ortiz O., Mares V. The historical, social, and economic importance of the potato crop. In: The potato genome. Compendium of Plant Genomes. S. Kumar Chakrabarti, C. Xie, J. Kumar Tivari (eds.). Springer, Cham, 2017: 1-10 (doi: 10.1007/978-3-319-66135-3_2).

5. Abhayapala K.M.R.D., De Costa W.A., Fonseka R.M., Prasannath K., De Costa D.M., Suriyagoda L.D.B., Abeythilakeratne P.D., Nugaliyadde M.M. Response of potato (Solanum tuberosum) to increasing growing season temperature under different soil management and crop protection regimes in the upcountry of Sri Lanka. Tropical Agricultural Research, 2014, 25(4): 555-569 (doi: 10.4038/tar.v25i4.8061).

6. Haverkort A.J., Franke A.C., Steyn J.M., Pronk A.A., Caldiz D.O., Kooman P.L. A Robust Potato Model: LINTUL-POTATO-DSS. Potato Res., 2015, 58: 313-327 (doi: 10.1007/s11540015-9303-7).

7. Rykaczewska K. The impact of high temperature during growing season on potato cultivars with different response to environmental stresses. Am. J. Potato Res., 2013, 4: 2386-2393 (doi: 10.4236/aips.2013.412295).

8. Deguchi T., Naya T., Wangchuk P., Itoh E., Matsumoto M., Zheng X., Gopal J., Iwama K. Aboveground characteristics, yield potential and drought tolerance in "Konyu" potato cultivars with large root mass. Potato Res., 2010, 53: 331-340 (doi: 10.1007/s11540-010-9174-x).

9. Legay S., Lefèvre I., Lamoureux D., Barreda C., Luz R.T., Gutierrez R., Quiroz R., Hoffmann L., Hausman J.F., Bonierbale M., Evers D., Schafleitner R. Carbohydrate metabolism and cell protection mechanisms differentiate drought tolerance and sensitivity in advanced potato clones (Solanum tuberosum L.). Funct. Integr. Genomics, 2011, 11(2): 275-291 (doi: 10.1007/s10142-010-0206-z).

10. Haas B., Kamoun S., Zody M., Jiang R., Handsaker R., Cano L. et al. Genome sequence and analysis of the Irish potato famine pathogen Phytophthora infestans. Nature, 2009, 461(7262): 393-398 (doi: 10.1038/nature08358).

11. Asano K., Kobayashi A., Tsuda S., Nishinaka M., Tamiya S. DNA marker-assisted evaluation of potato genotypes for potential resistance to potato cyst nematode pathotypes not yet invading into Japan. Breed. Sci., 2012, 62: 142-150 (doi: 10.1270/jsbbs.62.142).

12. Rogozina E.V., Teren't'eva E.V., Potokina E.K., Yurkina E.N., Nikulin A.V., Alekseev Ya.I. Multiplex PCR-based identification of potato genotypes as donors in breeding for resistance to diseases and pests. Agricultural Biology [Sel'skokhozyaistvennaya biologiya], 2019, 54(1): 19-30 (doi: 1015389/agrobiology.2019.1.19eng).

13. Hirsch C.N., Hirsch C.D., Feicher K., Coombs J., Zarka D., Van Deynze A., De Jong W., Veiltleux R.E., Jansky S., Dethke P., Douches D.S., Buel C.R. Retrospective view of North American potato (Solanum tuberosum L.) breeding in the $20^{\text {th }}$ and $21^{\text {st }}$ centuries. G3: Genes, Genomes, Genetics, 2013, 3: 1003-10013 (doi: 10.1534/g3.113.005595).

14. Spooner D.M., Ghislain M., Simon R. Jansky S.H., Gavrilenko T. Systematics, diversity, genetics, and evolution of wild and cultivated potatoes. Bot. Rev., 2014, 80(4): 283-383 (doi: 10.1007/s12229-014-9146-y).

15. Loginov Yu.P., Kazak A.A. Vestnik Kemerovskogo gosudarstvennogo universiteta, 2015,4 (1/61): 24-28 (in Russ.).

16. Hardigan M.A., Laimbeer F.P.E., Newton L., Crisovan E., Hamilton J.P., Vaillancourt B., Wiegert-Rininger K., Wood J.C., Douches D.S., Farré E.M., Veilleux R.E., Buell C.R. Ge- 
nome diversity of tuber-bearing Solanum uncovers complex evolutionary history and targets of domestication in the cultivated potato. PNAS USA, 2017, 114(46): E9999-E10008 (doi: 10.1073/pnas. 1714380114).

17. Zhang H., Mittal N., Leamy L.J., Barazani O., Song B.N. Back into the wild - apply untapped genetic diversity of wild relatives for crop improvement. Evol. Appl., 2017, 10(1): 5-24 (doi: 10.1111/eva.12434).

18. Gavrilenko T.A., Ermishin A.P. Vavilovskii zhurnal genetiki i selektsii, 2017, 21(1): 16-29 (doi: 1018699/VJ17/220) (in Russ.).

19. Simakov E.A., Sklyarova N.P., Yashina I.M. Metodicheskie ukazaniya po tekhnologii selektsionnogo protsessa kartofelya [Guidelines for technology of potato breeding]. Moscow, 2006 (in Russ.).

20. Zadina N., Vidner I., Maior M., Baresh I., Odegnal V., Baranek N., Bukasov S., Budin K., Kameraz A., Lekhnovich V., Kostina L., Bavyko N., Korneichuk V. Mezhdunarodnyi klassifikator SEV vidov kartofelya sektsii Tuberarium (Dun.) Buk. roda Solanum L. [CMEA International classifier of potato species of the section Tuberarium (Dun.) Buk. genus Solanum L.]. Leningrad, 1984 (in Russ.).

21. Budin K.Z., Kameraz A.YA., Bavyko N.F., Kostina L.I., Morozova E.V., Turuleva L.M. Izuchenie i podderzhanie obraztsov mirovoi kollektsii kartofelya. Metodicheskie ukazaniya. Leningrad, 1986 (in Russ.).

22. Eberchart S.A., Russel W.A. Stability parameters for comparing varieties. Crop Sci., 1966, (6)1: 36-40 (doi: 10.2135/cropsci1966.0011183X000600010011x).

23. Kasai K., Morikawa Y., Sorri V.A., Valkonen J.P.T., Gebhardt C., Watanabe K.N. Development of SCAR markers to the PVY resistance gene $R y_{a d g}$ based on a common feature of plant disease resistance genes. Genome, 2000, 43: 1-8 (doi: 10.1139/g99-092).

24. Mori K., Sakamoto Y., Mukojima N., Tamiya S., Nakao T., Ishii T., Hosaka K. Development of a multiplex PCR method for simultaneous detection of diagnostic DNA markers of five disease and pest resistance genes in potato. Euphytica, 2011, 180: 347-355 (doi: 10.1007/s10681011-0381-6).

25. Song Y.S., Hepting L., Schweizer G., Hartl L., Wenzel G., Schwarzfischer A. Mapping of extreme resistance to PVY $\left(R y_{s t o}\right)$ on chromosome XII using anther-culture-derived primary dihaploid potato lines. Theor. Appl. Genet., 2005, 111: 879-887 (doi: 10.1007/s00122-005-0010-7).

26. Biryukova V.A., Zhuravlev A.A., Abrosimova S.B., Kostina L.I., Khromova L.M., Shmyglya I.V., Morozova N.N., Kirsanova S.N. Doklady RASKHN, 2008, 6: 3-6 (in Russ.).

27. Schultz L., Cogan N.O.I., McLean K., Dale M.F.B., Bryan G.J., Forster J.W., Slater A.T. Evaluation and implementation of a potential diagnostic molecular marker for $\mathrm{H} 1$-conferred potato cyst nematode resistance in potato (Solanum tuberosum L.). Plant Breeding, 2012, 131: 315 321 (doi: 10.1111/j.1439-0523.2012.01949.x).

28. Ghislain M., Nunez J., del Rosario Herrera M., Rignataro J., Guzman F., Bonierbale M., Spooner D.M. Robust and highly informative microsatellite-based genetic identity kit for potato. Mol. Breeding, 2009, 23: 377-388 (doi: 10.1007/s11032-008-9240-0).

29. Sainakova A.B., Romanova M.S., Krasnikov S.N., Litvinchuk O.V., Alekseev Ya.I., Nikulin A.V., Terent'eva E.V. Vavilovskii zhurnal genetiki $i$ selektsii, 2018, 22(1): 18-24 (doi: 10.18699/VJ18.326) (in Russ.).

30. Sorokin O.D. Prikladnaya statistika na komp'yutere [Applied statistics on a computer]. Krasnoobsk, 2004 (in Russ.).

31. Dospekhov B.A. Metodika polevogo opyta: monografiya [Methods of field trials: A monograph]. Moscow, 1985 (in Russ.).

32. Castaneda-Alvarez N.P., de Haan S., Juarez H., Khoury C.K., Achicanoy H.A., Sosa C.C., Bernau V.V., Salas A., Heider B., Simon R., Maxted N., Spooner D. Ex situ conservation priorities for the wild relatives of potato (Solanum L. section Petota). PLoS ONE, 2015, 10(4): e0122599 (doi: 10.1371/journal.pone.0122599).

33. Bamberg J.B., del Rio A. Accumulation of genetic diversity in the US Potato Genebank. Am. J. Potato Res., 2016, 93(5): 430-435 (doi: 10.1007/s12230-016-9519-3).

34. Kim S.R., Ahn Y.K., Kim T.G., Kang H.S., Song S.W., Kim B.C., Kang S.G. Breeding of a new cultivar «Jeseo» with resistance to common scab. Korean J. Breed. Sci., 2013, 45: 468-473 (doi: 10.9787/KJBS.2013.45.4.468).

35. Quenouille J., Vassilakos N., Moury B. Potato virus Y: a major crop pathogen that has provided major insights into the evolution of viral pat hogenicity. Molecular Plant Pathology, 2013, 14(5): 439-452 (doi: 10.1111/mpp.12024).

36. Kogovsek P., Kladnik A., Mlakar J., Znidarie M.T., Dermastia M., Ravnikar M., PompeNovak M. Distribution of Potato virus Y in potato plant organs, tissues, and cells. Phytopathology, 2011, 101: 1292-1300 (doi: 10.1094/PHYTO-01-110020).

37. Karasev A.V., Grau S.M. Continuous and emerging challenges of Potato virus Y in potato. Annual Review of Phytopathology, 2013, 51: 571-586 (doi: 10.1146/annurev-phyto-082712-102332).

38. Massumi H., Poornohammadi S., Pishyar S., Maddahian M., Heydarnejad J., HosseniPouer A., Bysterveldt K., Varsani A. Molecular characterization and field survey of Iranian po- 
tato virus X isolates. VirusDisease, 2014, 25(3): 338-344 (doi: 10.1007/s13337-014-0222-z).

39. Senanayake D.M.J.B., Mandal B. Expression of symptoms, viral coat protein and silencing suppressor gene during mixed infection of a N-Wi strain of potato virus $\mathrm{Y}$ and an asymptomatic strain of potato virus X. VirusDisease, 2014, 25(3): 314-321 (doi: 10.1007/s13337-014-0204-1).

40. Gebhardt C. Bridging the gap between genome analysis and precision breeding in potato. Trends in Genetics, 2013, 29(4): 248-256 (doi: 10.1016/j.tig.2012.11.006).

41. Slater A.T., Cogan N.O., Forster J.W. Cost analysis of the application of markerassisted selection in potato breeding. Mol. Breeding, 2013, 32(2): 299-310 (doi: 10.1007/s11032-013-9871-7).

42. Zoteeva N.M., Antonova O.Yu., Klimenko N.S., Apalikova O.V., Carlson-Nilsson U., Karabitsina Yu.I., Ukhatova Yu.V., Gavrilenko T.A. Facilitation of introgressive hybridization of wild polyploid Mexican potato species using DNA markers of $R$ genes and of different cytoplasmic types. Agricultural Biology [Sel'skokhozyaistvennaya biologiya], 2017, 52(5): 964-975 (doi: 10.15389/agrobiology.2017.5.964eng).

43. Khyutti A.V., Antonova O.Yu., Mironenko N.V., Gavrilenko T.A., Afanasenko O.S. Vavilovskii zhurnal genetiki $i$ selektsii, 2017, 21(1): 51-61 (doi: 10.18699/VJ17.223) (in Russ.).

44. Albiski F., Najla S., Sanoubar R., Alkabani N., Murshed R. In vitro screening of potato lines for drought tolerance. Physiology and Molecular Biology of Plants, 2012, 18(4): 315-321 (doi: 10.1007/s12298-012-0127-5).

45. Alva A., Moore A., Collins H. Impact of deficit irrigation on tuber yield and quality of potato cultivars. Journal of Crop Improvement, 2012, 26: 211-227 (doi: 10.1080/15427528.2011.626891).

46. Anithakumari A.M., Nataraja K.N., Visser R.G.F., Van Der Linden C.G. Genetic dissection of drought tolerance and recovery potential by quantitative trait locus mapping of a diploid potato population. Mol. Breeding, 2012, 30(2): 1413-1429 (doi: 10.1007/s11032-012-9728-5).

47. Fanourakis D., Carvalho S.M.P., Almeida D.P.F., Heuvelink E. Avoiding high relative air humidity during critical stages of leaf ontogeny is decisive for stomatal functioning. Physiologia Plantarum, 2011, 142: 274-286 (doi: 10.1111/j.1399-3054.2011.01475.x).

48. Wang-Pruski G., Schofield A. Potato: improving crop productivity and abiotic stress tolerance. In: Improving crop resistance to abiotic stress. N. Tuteja, S.S. Gill, A.F. Tiburcio, R. Tuteja (eds.). Wiley-VCH Verlag GmbH \& Co. KGaA, 2012: 1121-1153 (doi: 10.1002/9783527632930.ch44). 